\title{
ROCKY CULTURAL - HISTORICAL HERITAGE "THE HOLY PATH"
}

\author{
Evgeni Koev \\ Faculty of History, Geography Dept., Universiy of Veliko Tarnovo \\ "St. St. Cyril and Methodius", Veliko Tarnovo, Bulgaria \\ ev_koeff@abv.bg
}

\begin{abstract}
The path, on which the relics of St. Ivan (John) of Rila were carried in 1469, from Veliko Tarnovo, through Nicopol and Sofia, to the Rila Monastery, goes through some regions, which have a wide diversity in natural geographical and cultural-historical features. Some of the most impressive parts of the route are the karst regions, in which there is a rock-hewn, cultural-historical heritage that still exists today and is of great interest. The examination and the recording of the data from this pilgrim route "The holy path" would be a good ground for its thorough research, preservation and exposure in a way which would increase its attractiveness

Keywords: The Holy Path; Karst Regions; Rock-Hewn Heritage; Cultural and Historical Heritage; Pilgrim Route
\end{abstract}

\section{НАСКААНОТО КУАТУРНО - ИСТОРИЧЕСКО НАСАЕАСТВО ПО „СВЕТИЯТ ПЪТ“}

\author{
Евгени Коев \\ Исторически фокултет, КатеАра „Геогафоия“, Великотьрновски \\ университет „Св.Св. Кирил и Метолий“, Велико Търново, България
}

Резюме: Пътят на пренасяне мощите на Св.Йоан Ри^ски през 1469 г, от Велико Търново през Никопол, Софоия Ао Рилския манастир преминава през изключително разнообразни в природно-географрско и културно-историческо отношение райони. ЕАни от най-впечатляващите участьци от маршрута са карстовите райони, в които съществуващото и Анес скално-изсечено, културно-историческо наслеАство представлява особен интерес. Обзорьт и описът на това наслеАство би преАставлявал Аобра основа за неговото цялостно проучване, опазване и експониране по начин, повишаващ атрактивността и привлекателността на пок^онническият маршрут „Светият път“.

КАючови Ауми: Светият Път, Карстови райони, скалноизсечено наслеАство, културно-историческо наслеАство, пок^оннически маршрут

"Светият пьт" - маршрутьт, по който са преминали рилските монаси със светите мощи на Св. Йоан Ри^ски през 1469 г. от Търново 
през Никопол, Софиия до Рилската Света обител, е еАин от изкАючително богатите на културно-историческо наследство маршрути в нашата страна. Част от това забележително наследство е наскалното културноисторическо наследство, голям процент от което е свързано с православната християнска цивилизация на Балканите. ЕАна значителна част от това наследство са поредицата скални храмове, манастири, килии, както и уникални запазени все още жилищни, битови, крепостни съорьжения, в преоблалаващата част оформени в карстовите райони, през които преминава маршрутьт. Проломьт „Аервеня" северно от гр. Велико Търново, районът на гр. Никопол, Аолното поречие на р. Осъм, както и проломите на р. Вит и р. Искър са съзАали изкАючително богати и разнообразни условия за живот, които нашите предци са оценили, населили и са оставили своето скално изсечено наслеАство.

Първите ярки паметници на среАновековното християнско скално наследство са непосредствено в началото на маршрута, в близост Ао гр. Велико Търново. СлеА напускане на града пьрвият обект, през който минава най-вероятният маршрут на връщане мощите на Рилския Чулотворец, е Патриаршеският манастир „Св Троица“. Това е еАин от най-ранните големи манастирски комплекси от сренновековната Търновска Света гора, чието начало е положено още през 11 век от „епитроп Георгий Преложник и синь му Калин“, , които съгражлат старата цьрква „Св Троица", завършена на 27 януари 1070 гол. (Beron, 2004) Сведения за манастира през средните векове получаваме и от житията на Св Теодосий Търновски и това на Св Патриарх Евтимий (Partenius, and Bonchev, 1991), в които е посочено еАнозначно, че монасите през този периол, са обитавали за по-льлго време или епизодично по време на пост, или при практикуване на исихазма като върховна форма на молитвено общение с Бог, поголеми и по-малки пещери и скални ниши, на които е богат ска^ният венец в района на манастира. При проучване наследството на обителта през последните десетилетия са установени, проучени и картирани запазените $А$ Анес скален паракАис - костница и скално жилище - постница, намиращи се в основата на скалния венец в североизточната част на двора на обителта (Koev, 2019). 
Непосредствено Ао „постницата", също в основата на скалния венец, южно от същата, в Аобре изразена, Аостатъчно голяма скална ниша, са запазени частично основите от преградните стени на Аруга найвероятно жилищна сграда или магерница, съществува^а в миналото'. В северната част в Авора на обителта, на нивото на основата на скалния венец са запазени и $А$ Анес стопански постройки С $ы$ ввена конструкция, монтирана към скалата. В същия район на еАно по-високо ниво на височина от оКо^о 6 м наА нивото на земята в еАНа От МалКИте пещери са запазени останки от прегрален зиА, изгрален от ^омени камъни на калова спойка, затварящ частично вхола на пещерата и превръщаш същата в килия. ПотвържАение за това са и запазените офрормени жлебове в скалата нал зила за монтиране на дьрвена конструкция, явно изпьлнявала ролята на каса на съществуващата Аьрвена врата². Интересен фокт в района на манастира „Света Троица" е и съществуването на пещера, Ао която води отвесен кулоар и изключително тесен, постепенно изкачващ се корниз, за която е запазено преданието, че това е пещерата, в която се е бил усамоти^ в молитвено усърдие Св Теодосий Търновски и където той е предсказал на своя ученик, бъдещият Патриарх Евтимий, че имено той ще бъАе предстоятел на Търновграл и че на него се пала тежкия крьст $а$ а защитава вярата и отечеството. Анес тази пещеричка, чиито вхол се извисява на около 20 метра нал земята е известна с името „Евтимиева пещера".

Като обобщение на описанието на обителта и съхраненото наскално наследство в нея, трябва да полчертаем, че запазените до Анес скално жилище - постница и скален паракАис са еАни от много малкото автентични в голямата си част съхранени образци от скалното архитектурно наслеАство и в частност - от скалните цьркви и скалните къщи в България (Koev, 2019).

\footnotetext{
1 Архив ПК „Аервент“ при ТА „Академик-ВТУ“" В.Търново, фоиш за теренни обхожАания с ръководител Евгени Коев // Archives PK "Dervent" at "Akademik-VTU", $\checkmark$.Tarnovo, Bulgaria, Work sheet for field walks with leader Evgeni Koev

2 Архив ПК „Аервент“ при ТА „Академик-ВТУ“" В. Търново. Карти на пещери в района на м-р Св.Троица // Archives PK "Dervent" at "Akademik-VTU", V.Tarnovo, Bulgaria, Maps of caves in the area of "Holy Trinity"
} 
Не в този мащаб, но също като съществена част от скалното наследство по маршрута, са И скалните ниши и малки пещери наА отстоящия срещуположно на манастира "Св Троица" , също средновековен манастир „Свето Преображение Господне“, който в своя пьрвоначален виА, може да се приеме, че е бил еАин от скалните манастири в района, а ако не е представлява^ типична скална обител, то със сигурност, от известните сведения за миналото на манастира, в него поне периодично, монашеското братство е използва^о за по $А$ он и молитвено усамотение скалните ниши и пещери в скалните венци нал манастира, каквито предания има Аокументирани и съхранени.

ИзкАючително Интересен обект, част от културно-историческото наслелство по маршрута е скалният манастир при гр. Никопол. Въпреки компрометирания към момента общ виА на манастира порали унищожените с времето Аьрвени конструкции и порали особеностите на твьрле меката и податлива на ерозия скала, $А$ онес е запазен общият вил на скалната цьрква „Св. Стеоран“" (Asparuhov, 1982). При обстоен оглеА и Анес могат $а$ а се откроят отАелните конструктивни елементи и части от храма. Наличните свидетелства за посрещането на рилските монаси в Никопол от описанието на пренасяне мощите на Св Йоан Рилски и Аруги извори, Аават убедителна инорормация, че по това време, втората половина на XV в. в грала са запазени и функционират различни православни храмове (Gyuzelev, 2004), (Kuzev, 1981), (Asparuhov, 1997). От описанието на гр. Никопо^ от В^алислав Граматик и от по-късните свеАения за града съществува инорормация, че в града са съществували 14 цьркви, което ни Аава достатьчно основание $\Delta$ а приемем, че през XV-XVI в., скалният манастир все още е бил еАно от тези свети меса в района. Запазените по стените в скалната цьрква налписи и рисунки свилетелстват за различни периоли от историята на храма - от среАновековието, та чак Ао началото на XX в, откогато също има запазени отАелни графити.

Аруг съществувал в миналото, а Анес трудно Аостьпен и забравен е средновековният манастир "Св Георги“, който е съществува^ $А$ XIX век. , за който свилетелства бивш кмет на гр. Плевен Иван Юрланов, а по-късно е описан и от акалемик ЮрАан Трифонов 
(Trifonov, 1933). Обителта е обхващала Аоминиращият наА околния реледр скален нос, известен като "Попската скала". Анес скалата остава запално наА язовирната стена, межАу Авата изградени и подьржани микроязовира наА "Тотлебеновия ва^" в местността "Кай^ька“ при гр. Плевен. Скромни свилетелства за съществуването на обителта са скалноизсечените стьпала и виещата се кьм нивото на манастира изсечена межАу скалите пьтека, водещи към нивото, кьАето е съществувал манастирския комплекс, който спореА проведените археологическите сонАажи в района е наслеАник на съществувала късноантична и средновековна крепост. В района на Анешния парк "Кай^ъка" са известни и множество скални ниши и пещери, някой от които и Анес се използват за различни цели и обогатяват преАставите ни за наскалното наслелство и антропогенизацията на карстовите райони Аори и Анес. Голямата пещера, в която е устроен ресторант „Кайлька“ е използвана още преди хиляАолетия за поселение от праисторическите хора. През изминалите Аесетилетия част от скалните ниши са би^и преустроени в заведения, паркинги, ведомствени бази, някой от които вече са изоставени, но Аруги се използват активно и Анес. СреА настоящите забележителности в парка е елинственият у нас, изцяло експониран в пещера, музей на виното.

Изк^ючително богат и интересен е районьт на с. Горталово, откьлето много вероятно са преминали рилските монаси. Каньоньт на р. Чернелка е известен в научните среди още от началото на XX в, когато там са документирани праисторически скални рисунки, които показват Аьлговечното обитаване на района и постепенната антропогенизация на карстовия ^анАшафт, приАоби^ на отАеАни места характерен облик. По Аолината на реката се минава край "Провьртеника"- уникален, изсечен в скалата цилиндричен отвор за черпене на вола, полобно на клаленец, свързващ Аиректно съществувалата наА скалите средновековна крепост със своеобразен вир от коритото на реката. Също нал левия бряг на река Чернелка съществува естествена малка пещера - скален параклис известна с името "Царева Аупка“, легендата за която свьрзва с послеАният цар на търновското царство, цар Иван Шишман. В района на самото село 
Съществуват Аесетки скално изсечени по-малки И големи ниши, някой от които са служили за изгражАане на скални жилища в тях, както и в някой естествени ниши и пещери. В "Голямата пещера" ("Горталовската пещера"), представляваща естествена просторна скална ниша с Аьлжина / Аьлбочина 1 1м. все още е запазена, вероятно посленната скална къща в България, състояща се от три жилищни помещения/стаи, с офрормена пред входа на старото жилище тераса, /пруст и тесен чардак/, стопанско помещение, изградено от ^омени камъни на калова основа с Аьрвени врата и прозорец, който жилищен комплекс е Аопьлнен и от отАелно изграден пещник (Koev, 2019). Имайки за образец това запазило се $\Delta о$ Анес скално жилище и съществуващите многобройни скални ниши с основание може $а$ се приеме, че в предните столетия, тези жилища са били далеч повече, както и Аа бълат приети преАанията, че част от тези скално изсечени ниши са използвани като тьрговски помещения / АЮкяни/, и че в еАна част от скално изсечените помещения, намиращи се Анес в северния край на селото, е съществувал скален манастир. Впечатляващ обект срел множеството споменати, безспорно е и "Сечената" или „Разцепената" скала, свързана с прелание за Крали Марко.

Много вероятния, възможен пункт, през които е преминала монашеската процесия и престояла поне за енна вечер, за отмора, полкрепа и възстановяване, е големия през средновековието Саловски манастир, просъществувал вероятно чак $л о$ средата XIXв. (Andreev, 1979). Анес от този значим културен и духовен центьр са запазени само основите от сграли и многоетажна каменна стражева кула. Старините от манастира са разположени на Аесния бряг на р. Вит, наА Анешното с. Саловец. На около петстотин метра, от Аругата страна на ^евия бряг на реката, към селото, се откроява група от няколко Аопьлнително обработени скални ниши и малка пещера, преАставлявали в миналото монашески килии и вероятно ма^ък парак^ис от скален скит към съществувалия в близост манастир.

Предание за съществуващ скален манастир е запазено и в пролома на река Вит, северно от с. ъглен. За съществуването му още се пазят спомени срел старите хора на селото, но мипсата $\Delta о$ 
момента, на по-подробни проучвания на обекта не позволяват подетайлното му описание. Съществуващите обаче скални ниши и малки пещери по скалният венец, извисяващ се и оорормящ Аесния бряг на реката, в същия район, Аава Аопьлнително основание $а$ б бье прието съществуването на споменатата обител в миналото. В същият район, в запалния край на скалния венец към селото е "Пещерата на живо изгорените". В пещерата ^ипсват слеАи от нарочна човешка Аейност за нейното Аооформяне, но са съхранените живи спомени от времето на войната межлу Руската и Османската империи за разигралата се човешка трагеАия.

Монтираният нал скалите православен крьст и провежлането на вече традиционни чествания, съхраняващи паметта за загиналите в пещерата ьгленци, определено дава основание, същата $\Delta а$ бъле причислена към скалните културно-исторически обекти по маршрута.

Особено богат на скално изсечени културно-исторически паметници е районьт на с. Карлуково. Ако трябва да проследим богатата история, процьфтявала и загльхвала в района, в известен хронологичен реА трябва $А$ наченем със скалната халка и Аопьлнително оорормени и издялани елементи, офоормщи впечатляващият стьлб с известните му всичания и площалки край него, известен с името „Провьртеника". Направените до сега различни наблюАения и проучвания сочат, че се касае за елин сложен археоастрономически, култов обект, преАставлявал място за наблюАение и почит към небесните светила. Вероятно полобни функции е имала и естествената пещера със скална ниша, известна Анес като средновековен скален скит „ГАигора“.

През средновековието и българското възраждане в района на гара Карлуково, освен големия манастир „Успение Богородично“, от който Анес е запазена единствено манастирската черква, съществуват И няколко скални обители / скитове /, които е възможно Аа са били част от еАин голям православен комплекс, като метоси на големия манастир, но също така е възможно и вероятно са съществували в определен периол от време, повече или по-малко и като самостоятелни обители. На левия бряг на реката са разположени скалният манастир „Св Никола" /ГАигора/ и пещерната обител „Св 
Безсребреници Козма и Аамян", в послеАният от които е съхранен и скален налпис от Св.Софрроний Врачански (Andreev, 1975). На Аесния бряг на р. Искър в скален венец нал коритото на реката, току пол Националния пещерен Аом е скалният манастир "Св Марина", известен, както и останалите обители, с фррагментите си от средновековни стенописи, част от които са свалени и се съхраняват в Националния исторически музей и РИМ гр Аовеч (Mavrodinova, 1985). И трите скални манастирчета, освен запазените храмове, са имали изградени в скалите ниши, монашески ки^ии, общи, заАоволяващи битовите и стопански нужАи, помещения и Аруги, характерни за всяка пьлноценно съществуваща обител.

Освен посочените скални обители, еАинодушно е мнението на изследователи, спелеолози , краеведи, че ако бьлат проведени редовни целенасочени проучвания, вероятно ще бъдат ^окализирани и Аруги монашески скитове, както и известно количество монашески килии, параклиси и Аруги, за което чудесна предпоставка са изобилстващите скални ниши и пещери (Mikov, 1933). Скалното наслелство в района се Аопьлва и от обитаваните през периолите на каменната и следващите ери пещери Прохолна и Темната дупка (Ророv, 1931). Последните години пещера Проходна е обект на изключителен интерес и антропогенни активности, като организиране на обучения, състезания, снимане на ориммови продукции, туристически посещения и Аруги. В последните гоАини огромният интерес към пещерата, промени и името, с което скалният мост при с. Карлуково придобива известност сред обществеността, с прозвището „Божиите очи“. От няколко гоАини на източната стена пол природното образувание "Окната" или „Божиите очи", с благословението на ^овешкия митрополит, е монтирана голяма икона „Исус Христос - Благославящ“. Този пример, наред с възстановяването на скалния манастир "Св.Марина" и укрепването, и полобряване Аостьпа до скалния манастир „Св Никола“, са показателни за непреходността и приемствеността при използването на наскалното културно-историческо наслеАство.

Наскалното наследство в Искърския пролом нал гара Карлуково се слива с богатото културно-историческо наследство в 
района на с. Кунино. Установените при археологически проучвания културни напластявания от палеолита и неолита в пещерите Самуилица, Провьртенка, Гьльбарника, показват още елин изключително богат район, населен от най-Аьлбока Аревност, които поселения са формирали и своята наскална култура, която Анес е наше общо ценно наследство (Dzambazov, 1959). Част от тези пещерни поселения Анес са със статут на „Паметник на културата с национално значение" или с такъв на "Приролна забележителност".

Много вероятно е маршрутьт на врьщане мощите на Св Йоан Ри^ски, от ри^ските монаси през 1469 гол. Аа е преминал през района на с. Камено поле.

В землището на селото, освен старата, средновековна, впечатляваща с размерите си и сьс запазена до преди няколко десетилетия средновековна живопис, базиликална черква, известна с името "Пустата цьрква“, съществуват и множество скални ниши и пещери, някой от които вероятно са използвани за монашески килии и обители. За землището на селото трябва да бъле полчертано, че там са установени поселения още от неолита и халколита, което полсказва Аобрите и преАпочитани условия за живот в този район още от Аьлбока Аревност. Землището е обитавано по време на траките, ранното, същинското, късно средновековие, та $\Delta$ о $а$ нес. Част от наскалното културно-историческо наследство по „Светият пьт“, въпреки че същото не е добре проучено към момента, е стаено по скалните венци в каньона на р. Ръчене, кълето „пьрвите останки от човешки обиталища / от палеолита - бел. Е.К./ намираме върху терасите и скалните навеси" (Petkov, 2010). Изобилстващите по поречието пещери, скални ниши и заслони са обитавани и през следващите исторически периоли (Petkov, 2010), което без съмнение е оставило своите слеАи и еАни позальлбочени, цялостни проучвания биха ^окализирали и осветлили това наше наслеАство.

Значимо наскално културно-историческо наследство са скалните ниши и пещери при с. Царевец, Врачанско, обитавани през различни исторически периоди, вкАючитеАно и през среАновековието от монаси исихасти. Скалните килии са известни с множество различни 
по време и виА скаАни рисунки на животни, космически сИмволи, рунически знаци и скално врязани налписи, преАставляващи кратка инорормация или посвещения (Prodanova, 1985).

Кьм поредицата от скални паметници трябва $А$ причислим и

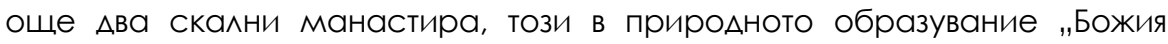
мост" (Todorova, 2012), който някои от запазените предания в района свързват с почитта към Свети равноапостоли цар Константин и царица Е^ена (Nikolova, 2012) и известния скален манастир „Св Йоан Ри^ски /Пусти/ " нал кв. Бистрец, северно от гр. Враца. (Ivanov, Todorova, and Pelova, 2011 ) И Авата скални манастира вероятно са продьлжение на т.н. вечно свети места, обожествени и превърнати в светилища с почит към скалата и водата още от Аревността и възприети като свещени и в християнството (Todorova, and Pavlova, 2009).

Особен интерес в манастира "Св Йоан Пусти" са запазените стенописи. Интерес прелставлява и съществувалата в миналото висока триетажна жилищно - храмова Аврвена сграда, изгралена в просторната скалната ниша /пещера/ с извор в основата на скалата. От ситуираната стенопис и наличните скални всичания за прикрепяне на съществувалата в миналото Аьрвена конструкция е виАно, че на найгорния етаж е бил храмьт на обителта, част от чиито стенописи са запазени и Ао днес. Манастирският комплекс се е простирал на няколко нива по скалните тераси и скални ниши, като на най-горното ниво, също в скална ниша/малка пещера/, е известната проучена и описана скална черква, украсена със запазена в известна степен стенопис, сред която е и изображението на Св Йоан Ри^ски. На скална п^ощаАка поА скалния храм, в слабо изразени ниши съществуват Аостатьчно скално изсечени елементи, подсказващи наличието в миналото на Аопьлнителни помещения, вероятно монашески килии, изградени също чрез използване на Аьрвени конструкции ${ }^{3}$.

Аруг забележителен паметник на скалното наследство по „Светият пьт" е средновековната крепост „Коритен грал“" при природния

${ }^{3}$ Архив ПК „Аервент“ при ТА „Академик-ВТУ“" В.Търново, фриш за теренни обхожАания с рьководител Евгени Коев // Archives PK "Dervent" at "Akademik-VTU", V.Tarnovo, Bulgaria, Work sheet for field walks with leader Evgeni Koev 
скален фенемен „Ритлите" - елна уникална крепост, изградена с умело използване на впечатляващите далености на местноста. Природния френомен „Ритлите“, офрормят източната окрайнина на еАин обхватен карстов район, с множество естествени пещери и скални ниши, същината на който район е Черепишкия манастир със запазения скален параклис - костница. Това е поредният обект, спалащ към поредицата от наскалното куртурно-историческо наслеАство по маршрута. Тук трябва $\Delta а$ бьле споменато и че в изобилстващия с десетки пещери район, някой от тях са свързани със живота на местното население, съществуват и такива, служили за монашески скитове или свързани със събития от национално-революционните борби на българския нарол (Vutov, 2002). Краят на най-големия поклоннически маршрут в България завьршва до пещерата на Св Йоан Рилски, която се явява послеАният Аом на Рилския чуАОтворец.

Пещерата е с офрормено стьлбище, тясна полица за палене на свещи и завършва с отвесен комин С възможен изхоА във височина "Провиралката". "Там не проникваше сльнце, нито повяваше вятьр, но само еАин ангел илваше при него, като му носеше манна от Бога във

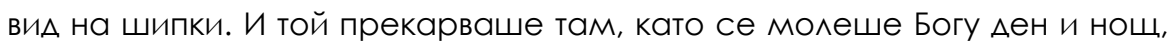
без почивка.." (Duychev, 1947). В непосредствена близост Ао пещерата е изворна чешма и молитвената скала, на която се е усамотявал преполобният „...и намери^ скала, с височина четирилесет сажена, а на ширина като голям щит. И той се възкачи^ на тази ска^а и прекара^ на нея седем години и четири месеца ... в Аенонощен пост и бление.." (Duychev, 1947).

Въпреки, че има различни вижАания за местата, които обитава Рилския Чулотворец, както и има различни мнения за това, къле са се намирали вековните дьрвета и пещерите, които са били полслон на Преполобния или молитвената скала /стьлпа/, на която той е бил найАълго време в пост и бление, то послеАната негова обител, както и чудесата, с които приживе се е прослави^ светият отец, е безспорно установена и оправлано пещерата на Св Йоан Рилски е приемана за еАно от светите места за православието. ЕАно от светите места, прието 
като прежлеосветено - още преживе от Свети Йоан Рилски, с което място се свързват и някой от чудесата извьршени от светеца.

При еАин най-общ преглеА на наскалното културноисторическо наследство по най-вероятния маршрут на пренасяне мощите на Св. Йоан Рилски от старата столица Велико Търново, през Никопол, Софрия Ао Рилския манастир, можем да откроим няколко групи скално изсечени или оформени в скален район обекти, представляващи част от нашето културно-историческо и Ауховно наследство. Някой от тях имат статут на паметници на културата с национално или местно значение, като пещерите Темната дупка и Самуилица. Аруги са известни, почитани от множество хора места като пещерата Прохонна /Божиите очи/ и, пещерата на Св. Йоан Ри^ски. Има и такива обекти, които са слабо известни и Аори може $а$ а се каже почти забравени като Садовския манастир със скалния скит на брега на р. Вит.

Част от послеАната група обекти са преоткрити в послеАните гоАини, някой от тях са възстановени, отбелязани с поАхоАящ знак, популяризират се или най-малко Аостьпьт $А$ тях е полобрен, като скалните манастири /скитове/ "Св. Марина" и "Св. Никола" при гара Карлуково, че Аори и скалния, бистрецки манастир „Св Йоан Ри^ски Пусти". Аруги все още не малко обекти от наскалното ни наслеАство по маршрута чакат своето профресионално проучване, Аокументиране, експониране и популяризиране като тези по р. Ръчене при с.Камено поле, някой от обектите при с. Горталово, при патриаршеския манастир "Св. Троица", при Черепишкия манастир и Аруги. Аруги известни и значими обекти, с представена немалко научна и популярна инорормация за тях нямат към настоящия момент възможен нормален Аостьп АО тях, което прави посещението на тези обекти труАно или наймалкото проблематично, като посещението на скалния храм „Св. Стедран" при гр. Никопол.

Ако обобщим и разграничим по определени белези споменатото по-горе наскално културно-историческо наслеАство по маршрута, то може да бъдат обособени няколко групи обекти, а именно - скални манастири, скални храмове /черкви, параклиси, Ар./, 
скални жилища /килии, заслони, къщи, Ар./ обекти свързани с живота по нашите земи по време на праисторическите хора, по време на траките, през средновековието, по време на българското възраждане и борбите за национално освобожление, както и такива от наше време. Може $а$ б бълат разграничени обекти с различни по виА и време скални рисунки и скални налписи с културно-историческо значение, обекти с битово предназначение и други. Като отАелна група могат $\Delta а$ бъдат обособени обекти, без забележими слеАи от човешка Аейност, но свьрзани с народната памет, почит, вяра.

В заключение, трябва да бъле отбелязано, че настоящото описание на наскалното културно-историческо наследство по „Светият пьт", обрьща внимание на по-важните и значими обекти от това наслелство по целия основен маршрут от Велико Търново Ао Рилската света обител.

Същото не обхваща всички обекти и не претендира за абсолютна изчерпателност по въпроса, което и не може $а$ б бъле изпьлнено в полобен ограничен обхват. Настоящата работа може $а$ а послужи за база на еАно бъАещо по-пьлно и обхватно описание на това ценно Ауховно, културно-историческо наслеАство, преАставляващо важен ресурс за развитие на поклонническия туристически маршрут, както и за развитие на отлелните поселения, които разполагат с това богатство. Обзорьт и описьт на това наслеАство би преАставлява^ Аобра основа за неговото цялостно проучване, опазване и експониране по начин, повишаващ атрактивността и привлекателността на пок^онническият маршрут „Светият път".

\section{AИTEPATYPA / REFERENCES}

Andreev, Y. (1979). The inscriptions at the Sadovski monastery (in Bulgarian), mag. "Vekove", 1979, .№3, 60-64, // [АнАреев,Й, (1979) Налписите при Саловския манастир, сп.Векове, 1979г.№3,60-64];

Andreev, Y. (1975). The inscriptions at the rock church "St. Bezsrebrenitsi" near Karlukovo station (in Bulgarian), mag."Vekove", 1975, №6, 46-55 // [АнАреев, Й. (1975) Налписите от скалната цьрква "Свети Безсребреници" при гара Карлуково, сп."Векове", 1975,№ 6, 46-55]; 
Asparuhov, M. (1997). Archaeological contributions to the history of medieval Nikopol (in Bulgarian), P. I (Library Bulgarian northwest to "Notices of museums in northwestern Bulgaria", 13) Vratsa, Bulgaria, 1997, 5-58 // [Аспарухов, М. . (1997) Археологически приноси към историята на средновековния Никопол. Ч. І (Библиотека Бьлгарски северозапал към „Известия на музеите в Северозапална България", 13). Враца, 1997, 5-58];

Asparuhov, M. (1982). The rock church "St. Stefan" near Nikopol and the graffiti in it (in Bulgarian), Notices of the museums in Northwestern Bulgaria, V. 7, Vratsa, Bulgaria, 1982, 28-45, // [Аспарухов, М. (1982) Скалната цьрква „Св. Стефран” край Никопол и графитите в нея. - Известия на музеите в Северозапална България. T. 7. Враца, 1982, 28-45];

Beron, V. (2004). Archaeological and historical research (in Bulgarian), Abagar, V. Tarnovo, Bulgaria, 75-84 // [Берон, В. (2004) Археологически и исторически изследвания, Абагар, В. Търново, 2004, стр 75-84];

Duychev, Iv. (1947). The Rila saint and his monastery (in Bulgarian), Sofia, Bulgaria, 1947, 105-111 // [Ауйчев, Ив. (1947) Рилският светец и неговата обител, Софрия 1947, 105, 111];

Dzambazov, N. (1959). Excavations in the Samuilitsa II cave (in Bulgarian), mag. "Archeology", 1959, № 1-2 // [Ажамбазов, Н. (1959) Разкопки в пещерата Самуимица ІІ. Сп. „Археология“, 1959, № 1 - 2];

Gyuzelev, V. (2004). History of Nikopol from antiquity to 1944 (in Bulgarian), Pleven, Bulgaria, 2004, 50-59 // [Гюзелев, В. (2004) История на Никопол от Аревноста Ао 1944 г. Плевен, 2004, 50-59];

Ivanov, P., K. Todorova, V. Pelova. (2011). Bistrets monastery St Ivan Rilski (Pusti (Deserted) - Kasinets (in Bulgarian), Vratsa, Bulgaria, (2011) // [Иванов, П^. К. Тодорова, В. Пелова, (2011) Бистрешки манастир "Св. Иван Ри^ски (Пусти) Касинец" - Враца : Регионално краеведско Аружество, 2011];

Koev, E. (2019). The rock houses in Bulgaria - the almost extinct heritage (in Bulgarian), In: Coll. Symposium in honor of the 60th anniversary of Prof. Rumen Yankov, HF, UVT "St.St. Kyril and Methodius", XI.2019 (in print) // [Коев, Е. (2019) Скалните къщи в България - почти загубеното наслеАство, Сборник „Симпозиум в чест на 60 гол. на Профр. Румен Янков“, ИФ, ВТУ „Св. Св. Кири^ и Методий“, ХІ.2019 (поА печат)];

Kuzev, A. (1981). Nikopol and Holavnik (in Bulgarian), In: Bulgarian medieval towns and fortresses, Volume I. Towns and fortresses along the Danube and the Black Sea, Varna,Bulgaria, 1981, 128-130 // [Кузев, А. (1981) Никопол и Хольвник. - В: Български средновековни градове и крепости. Т. І. Гралове и крепости по Аунав и Черно море, Варна, 1981, 128-130]; 
Mavrodinova, L. (1985). The rock hermitages near Karlukovo (in Bulgarian), Sofia, Bulgaria, 1985, 5, 48-49 // [Мавродинова, ^. (1985) Скалните скитове при Карлуково. С, 1985, стр 5, 48, 49];

Popov, R. (1931). The Dark hole, a new deposit from the Paleolithic in Bulgaria (in Bulgarian), Sofia, Bulgaria, SPH, 1931 // [Попов, P. (1931) Пещерата Темната Аупка, ново находище от, палеолита в България, С, АП, 1931];

Mikov, V. (1933). Prehistoric settlements and finds in Bulgaria (in Bulgarian), Sofia, Bulgaria, 1933 // [Миков, В. (1933) Предисторически селища и находки в България. С., 1933]

Partenius, Levk. Bish., A. Bonchev (1991). Lives of the Saints (in Bulgarian), Sinodal Publishing Hause, Sofia, Bulgaria, 1991, 53-56, 527-530, 591-593 // [^евк.епископ Партений, А.Бончев (1991) Жития на светиите, Синолално издателство, Софрия, 1991, 53-56, 527-530, 591-593];

Petkov, P. (2010). Kameno pole (in Bulgarian), Vratsa, Bulgaria, 2010, 10-22 // [Петков,П. (2010) Камено поле, Враца, 2010г,10 - 22];

Prodanova, B. (1985). For the rock inscriptions in the cave complex near the village of Tsarevets, Vratsa region (in Bulgarian), Diploma work, HF, UVT "St.St. Kyril and Methodius", 1985 // [Проданова,Б. (1985) За скалните налписи в пещерния комп^екс при с.Царевец, Врачанско, Аип^.работа, ИФ, ВТУ „Св.Св Кирил и Методий", 1985 г.];

Todorova, K. (2012). God's Bridge - natural and cultural - historical landmarks from the Vratsa region (in Bulgarian), Vratsa, Bulgaria, 2012, 30 - 33 // [ТоАорова, К. (2012) ,Божият мост - природни и културно-исторически забележителности от Врачанския край“, враца, 2012, стр 30 -33];

Todorova, K , S. Pavlova. (2009). Holy places - the churches and monasteries in the Vratsa region (in Bulgarian). In: Proceedings of the fifth regional conference on local lore, Vratsa, 27.XI.2008, Sofia, Bulgaria, 2009 // [Тодорова, К. С. Пав^ова (2009) Свети места - цьрквите и манастирите във Врачанския край : Сборник с материали от Петата регионална краеведска конореренция, Враца, 27.XI.2008 г. ,Софрия: Рал-Колобър, 2009];

Trifonov. Y. (1933). History of Pleven unit the Liberation war (in Bulgarian), Sofia, Bulgaria, 1933 // [Трифонов, Ю. (1933) История на Плевен до Освоболителната война, Софрия, 1933];

Vutov, P. (2002). Cherepis and Rzana (in Bulgarian), Sofia, Bulgaria, 2002, 11-19// [Вутов, П. (2002) „Черепиш и Ржана“ ,София, 2002, 11 - 19]. 


\section{КУАТУРНО-ИСТОРИЧЕСКО НАСАЕАСТВО: \\ ОПАЗВАНЕ, ПРЕАСТАВЯНЕ, АИГИТААИЗАЦИЯ}

\section{CULTURAL AND \\ HISTORICAL \\ HERITAGE}

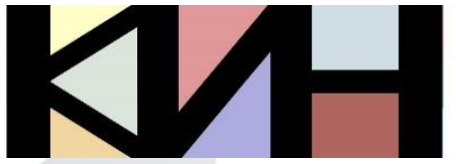

PRESERVATION PRESENTATION DIGITIZATION
Материалите в сборника са обект на авторско право. Разрешава се безвъзмезАното ползване на техни електронни/ хартиени копия само за лична употреба или обучение, при пь^но цитиране на текущата страница и слеА писмена декларация от цитиращия за Аипса на търговски намерения. За копиране пол Аруга фрорма, препубликуване или публикуване на сървъри се изисква писмено разрешение и/или заплащане.

() Авторски колектив, 2020 Техническо реАактори: Николай Ноев Калина Сотирова-Вълкова
This work is subject to copyright. Open and free of charge use of digital/hard copies of publications is granted only for personal or educational use, with full citation of the current page, and after written declaration of the quoting side for not-commercial Intention. For any other reproducing types, republishing, photocopying, recording, or any other storage retrieval system/ server written permission and/or fee is required.

(C) Authors` Group, 2020

Technical editors:

Nikolay Noev

Kalina Sotirova-Valkova

\section{Научна пореАица: том 6, брой 1 (8)/2020 Science series: vol. 6 , issue $1(8) / 2020$}

